International Journal of Engineering \& Technology, 7 (2.29) (2018) $451-456$
International Journal of Engineering \& Technology
WPC
Website www.sciencepubco.com/index.php/IJET
Research paper

\title{
The Relationship Between Corporate Social Responsibility Practices and Firm Performance of Domestic Banks in Malaysia.
}

\author{
Janartini Santhirasegar ${ }^{1 *}$ Suresh Ramakrishnan $^{2}$, Sanil S Hishan ${ }^{3}$, Noriza Mohd Jamal ${ }^{4}$ \\ ${ }^{1}$ Raffles University Iskandar, Malaysia \\ ${ }^{2}$ Faculty Of Management, Universiti Teknologi Malaysia, \\ ${ }^{3}$ Faculty Of Management, Universiti Teknologi Malaysia, \\ ${ }^{4}$ Faculty Of Management, Universiti Teknologi Malaysia, \\ *Corresponding Author E-Mail: Janartinis@gmail.com
}

\begin{abstract}
The focus on corporate social responsibility (CSR) has been active in the public attention within Malaysia for the past ten years, and as such has become a strength in many corporations' public relations as what demonstrate in the bank's campaign strategy. In fact, the importance of CSR initiatives may have a direct impact on the success of the business as many organizations worldwide have come under pressure to meet the terms of the international CSR standards and practices. Therefore, this study seeks to measure the level of CSR disclosure by domestic banks in Malaysia from the year 2008 until 2015. This study used content analysis method to identify the CSR activities and disclosure score that was obtained from annual reports and sustainability reports for the commercial banks. Overall, the findings indicate that commercial banks in Malaysia promotes important roles in community and philanthropy. Additionally, this study will also examine the relationship between CSR and firm performance of in commercial banks Malaysia from the year 2008 until 2015 . This study used correlation analysis to analyze the relationship between dependent variables, namely return on assets, return on equity and earnings per share, and independent variables which is the CSR disclosure. The overall sample results revealed only return on asset and return on equity has significant relationship with CSR. Thus, a greater profitability can be achieved through appropriate CSR practice. CSR reporting should not be a practice only for special or infrequent events rather it should be a continuous process, and banks need to incorporate CSR reporting more.
\end{abstract}

Keywords: Malaysia, Corporate Social Responsibility, Financial Performance, Commercial Banks

\section{Introduction}

In the past two decades a number of researchers have sought to determine the relationship between CSR and firm performance across various sector. In the early stages, most of the studies focus on the developed countries (Cochran \& Wood, 1984; Aupperle, Carroll, \& Hatfield, 1985; McGuire, Sundgren, \& Schneeweis, 1988; Cornett, Erhemjamts, \& Tehranian, 2014; Mackey, Barney, $\&$ Mackey, 2007). Later on, several researchers turned their attention to the emerging countries to investigate the effect of CSR (Mishra, \& Suar, 2010; Chen, \& Wang, 2011; Bidhari, Salim, \& Aisjah, 2013; Murtaza, Akhtar, \& Sadiqa, 2014). In recent years, several studies have focused on the cases in Malaysia. Majority of the studies in Malaysia presented a broad review of significant CSR impact on firm performance (Saleh, Zulkifli \& Muhamad, 2011; Mustafaa, Mustafa, Othman \& Perumal, 2012; Fuzi, Desa, Hibadullah, Zamri, \& Habidin, 2012). However Ramasamy, Ting
\& Yeung (2007) claimed that there is an insignificant impact of CSR on firm performance.

\subsection{Problem Statement}

Corporate Social Responsibility (CSR) practices are growing on a global scale and Malaysia is riding that momentum. The Malaysian government is one of the few in Asia to enact CSR reporting requirements for public listed companies. In the 2007 Budget Speech, the former Prime Minister of Malaysia, Abdullah Ahmad Badawi outlined the government's first tentative vision for CSR in Malaysia. All listed companies are required to report on CSR in their annual report since 31 December 2007 (Bursa Malaysia, 2006).

To illustrate the importance of CSR, Bursa Malaysia, the stock exchange of Malaysia, has issued a CSR framework for public listed companies in Malaysia. The framework is based on four main focal areas for CSR practice which are the environment, the 
workplace, the community and the marketplace, in no order of priority. The framework was designed to encourage Malaysian public listed companies to become more engaged in being socially responsible. Nazsli et al. (2003), stated that many public companies in Malaysia are slower in responding to the issue of CSR. There is less of literature available on this issue especially in Malaysia and that perhaps be one of the factors why firms are cautious in execution of CSR.

The banking sector in Malaysia has played a vital catalytic role to lift up the economic transformation and growth of the economy through the several stages of development. In order to assist the government in achieving the nation's vision, the banking institutions are expected to conduct their business in a more sustainable manner (Jeffreys, 2007). Besides that, banking sector is integrating economic, environmental, and social information into their public reports. Due to the changes of the landscape of Malaysian banking sector, various liberalization measures being introduced during the last decade including the importance of the sustainability disclosure, thus, this study therefore aims to measure the quality of the CSR disclosure by the domestic banks in Malaysia.

Nevertheless, the issue of CSR across domestic banks in Malaysia has not been given much attention by the researchers. This is one of the motivations of this study. The empirical analysis of the relationship between CSR and firm performance has yet to provide a convincing causal link between two variables (Mwangi \& Jerotich, 2013). Study on this relationship had mixed result whether it is positive, negative or no significant relationship between CSR and firm performance.

Problem surface in Malaysia corporate entity was the lack of transparency and commitment towards CSR. Additionally, the previous researches in Malaysia were mainly on top hundred listed firms. However to researcher's knowledge, there were no previous study in literature has investigated the relationship between CSR and firm performance across commercial banks in Malaysia. It is therefore necessary to do a comprehensive study about the relationship between CSR and firm performance across commercial banks in Malaysia. Therefore, this research focuses on identifying the relationship between CSR and the firm performance across domestic banks in Malaysia.

\subsection{Objective of The Study}

a)To study on the extent of CSR disclosures of public listed companies across domestic banks in Malaysia.

b)To examine the relationship between CSR and firm performance of domestic banks in Malaysia.

\section{Literature Review}

CSR contains a wide spectrum of issues ranging from business ethics, corporate governance and socially responsible investing to environmental sustainability and community investment (Shirley et al. 2009). CSR foresees the ideal whereby initiatives integrate social and environmental concerns in their business operations and their interaction with their stakeholders usually on a voluntary basis. CSR is about the behavior of businesses over and above what is generally required by regulatory bodies and legal requirements, not just because it is voluntarily practiced but because businesses believe it to be in their long-term interest to do so.

\subsection{Csr In Malaysia}

Malaysia has been an ardent exponent of the concept, with the government promoting and underlining the crucial role of CSR as a contributing factor to the country's growth. Malaysian Vision 2020 is geared towards pushing to rank the country among the fully developed nations. In the effort to achieve this, the country has ensured a strict implementation of its development plan the latest being the 11th Malaysian Development Plan (11MP). As an emerging nation, Malaysia has many challenges and deadlines to beat to cross over to the other side of the world. These include the famous Millennium Development Goals (MDGs) introduced by the $\mathrm{UN}$ in the recent years.

There was evidence of CSR in Malaysia, even way back in the 1980s, in terms of awareness and implementation (Teoh \& Thong, 1981). However, only in this past decade CSR has truly made a progress. Much to credit of the policies and initiatives of the federal government and its agencies (Sharma, 2013,Ramakrishnan et.al. 2016, Ramakrishnan et.al. 2016a). There are two major milestones in particular. The first is the launch of the "Silver Book" in May 2005, a set of CSR principles and guidelines for government linked companies in Malaysia (GLC Transformation Program Silver Book, 2005). Its objective is to assist government linked companies in incorporating CSR into their business agenda.

\subsection{Dependent Variables}

\subsubsection{Return on Assets (ROA)}

Return on equity measures the return earned on both preferred and common stockholders' investment in the financial institution annually. It shows the ability of generating profits from every unit of shareholders' equity. This ratio indicates the rate of return to shareholders for every dollar invested in the bank. The higher the ratio, the higher the rate of return. Significant and positive relationship between CSR and ROE was reported by Yusoff \& Adamu (2016); Malik \& Nadeem (2014); Mackey, Barney, \& Mackey (2007)

\subsubsection{Earnings Per Share (EPS}

Earnings per share (EPS) is the portion of the company's distributable profit which is allocated to each outstanding equity share. Earnings per share is a very good indicator of the profitability of any organization, and it is one of the most widely used measures of profitability. Growth in EPS is an important measure of management performance because it shows how much money the company is making for its shareholders, not only due to changes in profit, but also after all the effects of issuance of new shares. A number of authors have reported that CSR has significant relationships with EPS (Ahmed et al, 2016; Khan et al, 2016; Pan et al, 2014).

\subsection{Csr Disclosure Index}

There is various ways to measure CSR. The CSR disclosure index was created by Mehta \& Chandani (2015) based on the GRI Sustainability Reporting Guidelines Version 3.1 as part of a reference guidelines for reporting the CSR activities. Global Reporting Initiative (GRI) is an international organization established in 1997 with the aim to develop and promote international guidelines on sustainability reporting of companies and organizations.

This study used the most influential parameters of CSR that were designed on the basis of mandatory as well as some nonmandatory guidelines issued by Bursa Malaysia which includes CSR disclosures in annual report, CSR as corporate strategy, role of board of director in CSR policy of company, role of independent director in CSR, CSR as board agenda, sustainability report and its content, CSR committee, financial disclosures of CSR activities, percentage of profit towards CSR activities and inclusion of all stakeholders for CSR activities.

\subsection{Conceptual Framework}

This study focuses on the impact of CSR on firm performance. This study uses previous models and develops a model. CSR disclosure index is considered as independent variable while Return on Asset (ROA), Return on Equity (ROA) and Earnings per Share (EPS) as dependent variables to measure firm performance. Ac- 
cordingly, the framework of proposed study was illustrated in figure 2.1:

Independent Variable Corporate Social Responsibility

CSR Disclosure Index
Dependent Variables Firm Performance

\section{Return on Assets} Return on Equity Earnings per Share

Fig 2.1 Conceptual Framework on Independent and Dependent Variable

\section{Methodology}

\subsection{Research Design}

This study is using mixed method research design as it is the most appropriate research design to be used especially based on the nature of the hypothesis and the data required. According to Creswell et al. (2003), a mixed methods study involves the collection or analysis of both quantitative and qualitative data in a single study in which the data are collected concurrently or sequentially, are given a priority, and involve the integration at one or more stages in the process of research. Qualitative data analysis for this study is more concentrated on analyzing annual reports of Malaysia from year 2008-2015.

\subsection{Population and Sampling}

The population and the sample of this study comprises of eight domestic banks in Malaysia as listed by the Bank Negara Malaysia (BNM). The sample represents among the successful local commercial banks in Malaysia. Each of these banks had practiced CSR continuously for a minimum period of five years.

\subsection{Hypotheses}

Based on the literature revised in Chapter 2, the hypotheses of the study are as below:

$H_{0=}$ There is no correlation between CSR practices of corporate and its financial

\section{performance}

$H_{1=}$ There is a correlation between CSR practices of corporate and its financial

performance.

\subsection{Content Analysis}

The data that was obtained for this study based on content analysis method. Sapsford \& Jupp (2006) defined it as "a method of analysing the contents of documents that uses quantitative measures of the frequency of appearance of particular elements in the text". Content analysis is most often viewed in CSR as "a technique for gathering data that consists of codifying qualitative information in

anecdotal and literary form into categories in order to derive quantitative scales of varying levels of complexity" (Abbot and Monsen, 1979). Thus, it is a research technique for making replicable and valid inferences from data according to their context and this technique has been readily applied and widely used in corporate social disclosure-based research (Harun et al, 2013). This study adopted the methodological approach developed by Mehta \& Chandani (2015). This content analysis will involve tracing of sentences of each component of the corporate social responsibility disclosed in annual reports of domestic banks Malaysia in the sample. Then the following criteria for CSR will be taken and weightage are assigned as per their significance.

CSR criteria were developed into a form of index known as CSR disclosure index (CSRD index) based on the GRI Sustainability Reporting Guidelines Version 3.1 as part of a reference guidelines for reporting the CSR activities. CSRD index were develop from those criteria to examine the level of performance and practice of Malaysian domestic banks according to its dimensions. After assigning the weightage, the disclosure have to be evaluated on the basis of the quality of the disclosure. If disclosure is disclosed efficiently then score gets $100 \%$ of the weightage and if it is not disclosed at all then zero is assigned.

Table 1 Criteria for research - CSR

\begin{tabular}{|l|l|c|}
\hline No. & \multicolumn{1}{|c|}{ Criteria } & $\begin{array}{c}\text { Weightage } \\
\text { in \% }\end{array}$ \\
\hline $\mathbf{1}$ & CSR Disclosures in Annual report & 10 \\
\hline $\mathbf{2}$ & CSR as Corporate Strategy & 10 \\
\hline $\mathbf{3}$ & $\begin{array}{l}\text { Role of Board of Director in CSR policy of com- } \\
\text { pany }\end{array}$ & 10 \\
\hline $\mathbf{4}$ & Role of Independent Director in CSR & 10 \\
\hline $\mathbf{5}$ & CSR as Board Agenda & 10 \\
\hline $\mathbf{6}$ & Sustainability report and its content & 10 \\
\hline $\mathbf{7}$ & CSR Committee & 10 \\
\hline $\mathbf{8}$ & Financial disclosures of CSR activities & 10 \\
\hline $\mathbf{9}$ & Percentage of profit towards CSR activities & 10 \\
\hline $\mathbf{1 0}$ & Inclusion of all stakeholders for CSR activities & 10 \\
\hline \multicolumn{2}{|c|}{ TOTAL } & 100 \\
\hline
\end{tabular}

\subsection{Correlation Analysis}

This study have used correlation method to understand the relationship between CSR practices and firm performance of banking industry. Pearson correlation is used as a measure of the strength of a relationship between two variables and tested their significance. It is widely used in the sciences as a measure of the strength of linear dependence between two variables. Pearson correlation coefficient is a measure of the linear correlation between two variables. In order to evaluate the correlation between two variables it is important to be known its strength but also its significance (Lungu, Caraiani, \& Dascălu, 2011). After collecting the data from the annual reports of the companies, the correlation will be calculated with the help of Microsoft Excel sheet. Finally the conclusion can be drawn on the basis of correlation results.

\section{Results}

\subsection{Content Analysis}

\subsubsection{Affin Bank Berhad}

Table 2 CSR disclosure index of Affin Bank Berhad

\begin{tabular}{|c|c|c|c|c|c|c|c|c|}
\hline CSR Criteria & 2008 & 2009 & 2010 & 2011 & 2012 & 2013 & 2014 & 2015 \\
\hline CSR Disclosures in Annual report & 10 & 10 & 10 & 10 & 10 & 10 & 10 & 10 \\
\hline CSR as Corporate Strategy & 10 & 10 & 10 & 10 & 10 & 10 & 10 & 10 \\
\hline Role of Board of Director in CSR policy of company & 10 & 10 & 10 & 10 & 10 & 10 & 10 & 10 \\
\hline CSR as Board Agenda & 0 & 0 & 0 & 10 & 10 & 10 & 10 & 10 \\
\hline Sustainability report and its content & 0 & 0 & 0 & 0 & 0 & 0 & 0 & 0 \\
\hline CSR Committee & 0 & 0 & 0 & 0 & 0 & 0 & 0 & 0 \\
\hline Financial disclosures of CSR activities & 10 & 10 & 10 & 10 & 10 & 10 & 10 & 10 \\
\hline
\end{tabular}




\begin{tabular}{|c|c|c|c|c|c|c|c|c|}
\hline Percentage of profit towards CSR activities & 10 & 10 & 10 & 10 & 10 & 10 & 10 & 10 \\
\hline Inclusion of all stakeholders for CSR activities & 0 & 0 & 0 & 0 & 0 & 0 & 0 & 0 \\
\hline Total & 50 & 50 & 50 & 60 & 60 & 60 & 60 & 60 \\
\hline
\end{tabular}

\subsubsection{Alliance Bank Malaysia Berhad}

Table 3 CSR disclosure index of Alliance Bank Malaysia Berhad

\begin{tabular}{|c|c|c|c|c|c|c|c|c|}
\hline CSR Criteria & 2008 & 2009 & 2010 & 2011 & 2012 & 2013 & 2014 & 2015 \\
\hline CSR Disclosures in Annual report & 10 & 10 & 10 & 10 & 10 & 10 & 10 & 10 \\
\hline CSR as Corporate Strategy & 10 & 10 & 10 & 10 & 10 & 10 & 10 & 10 \\
\hline Role of Board of Director in CSR policy of company & 10 & 10 & 10 & 10 & 10 & 10 & 10 & 10 \\
\hline Role of Independent Director in CSR & 10 & 10 & 10 & 10 & 10 & 10 & 10 & 10 \\
\hline CSR as Board Agenda & 10 & 10 & 10 & 10 & 10 & 10 & 10 & 10 \\
\hline Sustainability report and its content & 10 & 10 & 10 & 10 & 10 & 10 & 10 & 10 \\
\hline CSR Committee & 10 & 10 & 10 & 10 & 10 & 10 & 10 & 10 \\
\hline Financial disclosures of CSR activities & 10 & 10 & 10 & 10 & 0 & 10 & 10 & 10 \\
\hline Percentage of profit towards CSR activities & 10 & 10 & 10 & 10 & 10 & 10 & 10 & 10 \\
\hline Inclusion of all stakeholders for CSR activities & 10 & 10 & 10 & 10 & 10 & 10 & 10 & 10 \\
\hline Total & 100 & 100 & 100 & 100 & 90 & 100 & 100 & 100 \\
\hline
\end{tabular}

\subsubsection{AmBank (M) Berhad}

Table 4 CSR Disclosure Index of AmBank (M) Berhad

\begin{tabular}{|c|c|c|c|c|c|c|c|c|}
\hline CSR Criteria & 2008 & 2009 & 2010 & 2011 & 2012 & 2013 & 2014 & 2015 \\
\hline CSR Disclosures in Annual report & 10 & 10 & 10 & 10 & 10 & 10 & 10 & 10 \\
\hline CSR as Corporate Strategy & 10 & 10 & 10 & 10 & 10 & 10 & 10 & 10 \\
\hline Role of Board of Director in CSR policy of company & 10 & 10 & 10 & 10 & 10 & 10 & 10 & 10 \\
\hline CSR as Board Agenda & 10 & 10 & 10 & 10 & 10 & 10 & 10 & 10 \\
\hline Sustainability report and its content & 10 & 10 & 10 & 10 & 10 & 10 & 10 & 10 \\
\hline CSR Committee & 0 & 0 & 0 & 0 & 0 & 0 & 0 & 0 \\
\hline Financial disclosures of CSR activities & 10 & 10 & 10 & 10 & 10 & 10 & 10 & 10 \\
\hline Percentage of profit towards CSR activities & 10 & 10 & 10 & 10 & 10 & 10 & 10 & 10 \\
\hline Inclusion of all stakeholders for CSR activities & 10 & 10 & 10 & 10 & 10 & 10 & 10 & 10 \\
\hline Total & 90 & 90 & 80 & 80 & 80 & 80 & 80 & 80 \\
\hline
\end{tabular}

\subsubsection{CIMB Berhad}

Table 5 CSR Disclosure Index of CIMB Berhad

\begin{tabular}{|c|c|c|c|c|c|c|c|c|}
\hline CSR Criteria & 2008 & 2009 & 2010 & 2011 & 2012 & 2013 & 2014 & 2015 \\
\hline CSR Disclosures in Annual report & 10 & 10 & 10 & 10 & 10 & 10 & 10 & 10 \\
\hline CSR as Corporate Strategy & 10 & 10 & 10 & 10 & 10 & 10 & 10 & 10 \\
\hline Role of Board of Director in CSR policy of company & 10 & 10 & 10 & 10 & 10 & 10 & 10 & 10 \\
\hline CSR as Board Agenda & 10 & 10 & 10 & 10 & 10 & 10 & 10 & 10 \\
\hline Sustainability report and its content & 0 & 0 & 10 & 10 & 10 & 10 & 10 & 10 \\
\hline CSR Committee & 10 & 10 & 10 & 10 & 10 & 10 & 10 & 10 \\
\hline Financial disclosures of CSR activities & 10 & 10 & 10 & 10 & 10 & 10 & 10 & 10 \\
\hline Percentage of profit towards CSR activities & 10 & 10 & 10 & 10 & 10 & 10 & 10 & 10 \\
\hline Inclusion of all stakeholders for CSR activities & 10 & 10 & 10 & 10 & 10 & 10 & 10 & 10 \\
\hline Total & 80 & 80 & 90 & 90 & 90 & 90 & 90 & 90 \\
\hline
\end{tabular}

\subsubsection{Hong Leong Bank Berhad}

Table 4.5: CSR Disclosure Index of Hong Leong Bank Berhad

\begin{tabular}{|c|c|c|c|c|c|c|c|c|}
\hline CSR Criteria & 2008 & 2009 & 2010 & 2011 & 2012 & 2013 & 2014 & 2015 \\
\hline CSR Disclosures in Annual report & 10 & 10 & 10 & 10 & 10 & 10 & 10 & 10 \\
\hline CSR as Corporate Strategy & 10 & 10 & 10 & 10 & 10 & 10 & 10 & 10 \\
\hline Role of Board of Director in CSR policy of company & 10 & 10 & 10 & 10 & 10 & 10 & 10 & 10 \\
\hline CSR as Board Agenda & 0 & 10 & 10 & 10 & 10 & 10 & 10 & 10 \\
\hline Sustainability report and its content & 10 & 10 & 10 & 10 & 10 & 10 & 10 & 10 \\
\hline CSR Committee & 0 & 0 & 0 & 0 & 0 & 0 & 0 & 0 \\
\hline Financial disclosures of CSR activities & 0 & 0 & 0 & 0 & 0 & 0 & 0 & 0 \\
\hline Percentage of profit towards CSR activities & 0 & 0 & 0 & 0 & 0 & 0 & 0 & 0 \\
\hline Inclusion of all stakeholders for CSR activities & 10 & 10 & 10 & 10 & 10 & 10 & 10 & 10 \\
\hline Total & 50 & 60 & 60 & 60 & 60 & 60 & 60 & 60 \\
\hline
\end{tabular}

\subsubsection{Maybank Berhad}

Table 7 CSR Disclosure Index of Maybank Berhad

\begin{tabular}{|c|c|c|c|c|c|c|c|c|}
\hline CSR Criteria & 2008 & 2009 & 2010 & 2011 & 2012 & 2013 & 2014 & 2015 \\
\hline CSR Disclosures in Annual report & 10 & 10 & 10 & 10 & 10 & 10 & 10 & 10 \\
\hline CSR as Corporate Strategy & 10 & 10 & 10 & 10 & 10 & 10 & 10 & 10 \\
\hline Role of Board of Director in CSR policy of company & 10 & 10 & 10 & 10 & 10 & 10 & 10 & 10 \\
\hline CSR as Board Agenda & 0 & 10 & 10 & 10 & 10 & 10 & 10 & 10 \\
\hline Sustainability report and its content & 10 & 10 & 10 & 10 & 10 & 10 & 10 & 10 \\
\hline CSR Committee & 0 & 0 & 0 & 0 & 0 & 0 & 0 & 0 \\
\hline Financial disclosures of CSR activities & 10 & 10 & 10 & 10 & 10 & 10 & 10 & 10 \\
\hline
\end{tabular}




\begin{tabular}{|l|l|l|l|l|l|l|l|l|}
\hline Percentage of profit towards CSR activities & 10 & 10 & 10 & 10 & 10 & 10 & 10 & 10 \\
\hline Inclusion of all stakeholders for CSR activities & 10 & 10 & 10 & 10 & 10 & 10 & 10 & 10 \\
\hline Total & 70 & 80 & 80 & 80 & 80 & 80 & 80 & 80 \\
\hline
\end{tabular}

\subsubsection{Public Bank Berhad}

Table 8 CSR disclosure index of Public Bank Berhad

\begin{tabular}{|c|c|c|c|c|c|c|c|c|}
\hline CSR Criteria & 2008 & 2009 & 2010 & 2011 & 2012 & 2013 & 2014 & 2015 \\
\hline CSR Disclosures in Annual report & 10 & 10 & 10 & 10 & 10 & 10 & 10 & 10 \\
\hline CSR as Corporate Strategy & 10 & 10 & 10 & 10 & 10 & 10 & 10 & 10 \\
\hline Role of Board of Director in CSR policy of company & 10 & 10 & 10 & 10 & 10 & 10 & 10 & 10 \\
\hline CSR as Board Agenda & 10 & 10 & 10 & 10 & 10 & 10 & 10 & 10 \\
\hline Sustainability report and its content & 10 & 10 & 10 & 10 & 10 & 10 & 10 & 10 \\
\hline CSR Committee & 10 & 10 & 10 & 10 & 10 & 10 & 10 & 10 \\
\hline Financial disclosures of CSR activities & 10 & 10 & 10 & 10 & 10 & 10 & 10 & 10 \\
\hline Percentage of profit towards CSR activities & 10 & 10 & 10 & 10 & 10 & 10 & 10 & 10 \\
\hline Inclusion of all stakeholders for CSR activities & 10 & 10 & 10 & 10 & 10 & 10 & 10 & 10 \\
\hline Total & 100 & 100 & 100 & 100 & 100 & 100 & 100 & 100 \\
\hline
\end{tabular}

\subsubsection{RHB Bank Berhad}

Table 9 CSR Disclosure Index of RHB Bank Berhad

\begin{tabular}{|c|c|c|c|c|c|c|c|c|}
\hline \\
\hline CSR Criteria & 2008 & 2009 & 2010 & 2011 & 2012 & 2013 & 2014 & 2015 \\
\hline CSR Disclosures in Annual report & 10 & 10 & 10 & 10 & 10 & 10 & 10 & 10 \\
\hline CSR as Corporate Strategy & 10 & 10 & 10 & 10 & 10 & 10 & 10 & 10 \\
\hline Role of Board of Director in CSR policy of company & 10 & 10 & 10 & 10 & 10 & 10 & 10 & 10 \\
\hline CSR as Board Agenda & 10 & 10 & 0 & 10 & 10 & 10 & 10 & 10 \\
\hline Sustainability report and its content & 0 & 10 & 0 & 10 & 10 & 10 & 10 & 10 \\
\hline CSR Committee & 10 & 10 & 0 & 10 & 10 & 10 & 10 & 10 \\
\hline Financial disclosures of CSR activities & 10 & 10 & 0 & 0 & 0 & 0 & 10 & 10 \\
\hline Percentage of profit towards CSR activities & 10 & 10 & 0 & 10 & 10 & 10 & 10 & 10 \\
\hline Inclusion of all stakeholders for CSR activities & 10 & 10 & 10 & 10 & 10 & 10 & 10 & 10 \\
\hline Total & 80 & 100 & 50 & 90 & 90 & 90 & 100 & 100 \\
\hline
\end{tabular}

\subsection{Correlation between CSR and Firm Performance}

Table 10 Overall Correlation Matrix of CSR and Firm Performance for Domestic Banks

\begin{tabular}{|l|l|l|l|l|}
\hline & \multicolumn{1}{|c|}{ CSR } & ROA & ROE & $0.2478 * *$ \\
\hline CSR & 1 & $0.2298^{* *}$ & 0.0571 \\
\hline ROA & & 1 & $0.7353^{* *}$ & $0.4967 * *$ \\
\hline EPS & & & 1 & $0.5697 * *$ \\
\hline
\end{tabular}

**. Correlation is significant at the 0.05 level (2-tailed).

Table 4.9 shows the correlations between CSR and firm performance across Malaysian banking sector. The sample consists of 8 local banks-year observations from 2008 to 2015. The independent variables used in this study are CSR Disclosure Index.

Table 10 provides an overall correlation analysis based on eight domestic commercial banks in Malaysia. The result shows that return on asset and return on equity is positively and significantly correlated to CSR at 5\% level. This indicates the CSR activities within the commercial banks are highly related and it contributes to the bank's ROA and ROE. On the other hand, earnings per share have an insignificant positive relationship with CSR. From the result, it shows that CSR has direct relationship with both ROA and ROE for this model. This result indicates, that every unit increase in CSR, the bank's ROA will increase by 0.23 units, meanwhile for ROE, every unit increase in CSR, bank's ROE will increase by 0.25 units. This result support the correlation test indicates there is significant and positive relationship between CSR with ROA and ROE. There is insufficient evidence to conclude that there is a significant linear relationship between CSR and financial performance because the correlation of EPS is not significant. Therefore, the null hypothesis is not rejected.

\section{Discussion}

The first research objective is to study on the extent of CSR disclosures of public listed companies across commercial banks in Malaysia. Based the content analysis, it is found that all the banks disclosed information related to environment and community involvement. The CSR disclosure certainly reflected the banks effort in showing what they have done and accomplish in various CSR categories. This supports the Legitimacy theory where the banks continually seek to ensure that they operate within the bounds and norms of their respective societies. In adopting a legitimacy theory perspective, the bank would voluntarily report on activities if management perceived that those activities were expected by the communities in which it operates. Campbell, Craven and Shrives (2003) examined the extent to which voluntary disclosures represent an attempt to close a perceived legitimacy gap.

Referring back to the most common of all CSR initiatives by the eight banks reported in the previous chapter, the "community" category seems to be the area where most banks concentrate their efforts when reporting their philanthropic activities being a highly publicized activity. This is because a correct social investment can benefit the company by having strong community relations and in order hand strengthen the image of the company. Most banks in Malaysia focuses their brand of CSR more heavily on philanthropy and charity rather than bottom-up sustainability initiatives. Whilst there is nothing wrong with this, it makes for a much skewed CSR portfolio rather than a corrective action and adaption in the way of doing business in changing times.

The finding supports the argument proposed by Chapple and Moon (2005). They claim that although different countries in Asia focus on different aspect of CSR, most of the business corporations in developing countries such as Malaysia are more associated with community and environmental commitments. Culture and philanthropic activities are other program that have received support from financial industry in Malaysia. 
Research objective 2 attempts to discover the relationship between CSR and the firms' performance. According to the results illustrated in previous chapter, all the eight local banks have a positive relationship between CSR and firm performance. The results have shown that the CSR disclosure index is positively related to ROA, ROE and EPS. This finding supports vast number of previous studies on the relationship between CSR and firm performance which recommended that adherence with CSR best practices would lead to a better firm performance. However, the findings of this study should be specifically interpreted because this study is purely based on the eight domestic banks in Malaysia.

The finding is consistent with the previous studies (Yusoff \& Adamu, 2016; Mehta \& Chandani, 2015; Wan Ahamed, Almsafir, \& Al-Smadi, 2014). In fact, Wan Ahamed, Almsafir, \& Al-Smadi (2014) strongly supported this finding by stating that the firms exhibit greater concern to improve financial performance and corporate reputation via increasing their CSR or sustainability report in their annual report.

Despite the fact that the idea of CSR within the banking sector seems to be popular as all the banks are involved in outlining their CSR engagement strategies. It is thus expected that the majority of the banks tend to engage in CSR-based strategies in order to increase their image within the general public by way of engaging in ad hoc community-based activities. Banks may also be seen to engage in CSR-based activities in order to enhance their brand reputation and also to enhance their image amongst the general public.

The banks in this study may be building a sustainable future for their investors, employees and other stakeholders. However, unless material information is disclosed in a continuous and timely way it is hard to determine whether this CSR initiative really achieved its main genuine purpose

\section{References}

[1] Abbott, W. F., \& Monsen, R. J. (1979). On the measurement of corporate social responsibility: Self-reported disclosures as a method of measuring corporate social involvement. Academy of Management journal, 22(3), 501-515

[2] Ahmed, M. N., Zakaree, S., \& Kolawole, O. O. (2016). Corporate Social Responsibility Disclosure and Financial Performance of Listed Manufacturing Firms in Nigeria. Research Journal of Finance and Accounting, 7(4), 47-58.

[3] Aupperle, K. Carroll, A. \& Hatfield, J. (1985, Jun). An empirical examination of the relationship between corporate social responsibility and profitability. Academy of Management Journal, 28(2), 446-463.

[4] Bidhari, S. C., Salim, U., \& Aisjah, S. (2013). Effect of corporate social responsibility information disclosure on financial performance and firm value in banking industry listed at Indonesia stock exchange. European Journal of Business and Management, 5(18), 39-46.

[5] Campbell, D., Craven, B., \& Shrives, P. (2003). Voluntary social reporting in three FTSE sectors: a comment on perception and legitimacy. Accounting, Auditing \& Accountability Journal, 16(4), 558-581.

[6] Carroll, A. B. (1979). A three-dimensional conceptual model of corporate performance. Academy of management review, 4(4), 497-505.

[7] Chapple, W., \& Moon, J. (2005). Corporate social responsibility (CSR) in Asia: a seven-country study of CSR web site reporting. Business \& society, 44(4), 415-441.

[8] Chen, H. H. \& Wang, X. Y. (2011). Corporate Social Responsibility and Corporate Financial Performance in China: An Empirical Research from Chinese Firms, Corporate Governance: The International Journal of Business in Society, 11 361-370.

[9] Cochran, P., \& Wood, R. (1984, March). Social Responsibility and Financial Performance. The Academy of Management Journal. 27, 42-56.

[10] Cornett, M. M., Erhemjamts, O., \& Tehranian, H. (2014). Corporate Social Responsibility and its Impact on Financial Performance: Investigation of U.S. Commercial Banks. Academy of Management Review, 14(1), 65-107.

[11] Creswell, J. W., Plano Clark, V. L., Gutmann, M. L., \& Hanson, W. E. (2003). Advanced mixed methods research designs. Handbook of mixed methods in social and behavioral research, 209-240.

[12] Fuzi, N. M., Desa, A. F. N. C., Hibadullah, S. N., Zamri, F. I. M., \& Habidin, N. F. (2012). Corporate social responsibility practices (CSR) and CSR performance in Malaysian automotive industry. International Journal of Accounting and Financial Reporting, 2(2), 268.
[13] GLC Transformation Program Silver Book. (2005). Retrieved from Putrajaya Committee on GLC High Performance: http://www.pcg.gov.my/trans manual.asp

[14] Harun, N. A., Rashid, A. A., \& Alrazi, B. (2013). Measuring the Quality of Sustainability Disclosure in Malaysian Commercial Banks.

[15] Khan, F., Rahman, M., MD. Waliullah, \& Tanu, M. T. (2016, February). Impact of corporate social responsibility expenditures on bank's financial performance: A study on the Southeast Bank Ltd. International Journal of Multidisciplinary Research and Development, 3(2), 271-276.

[16] Lungu, C. I., Caraiani, C., \& Dascălu, C. (2011). Research on corporate social responsibility reporting. The Amfiteatru Economic Journal, 13(29), 117-131.

[17] Mackey, A., Mackey, T. B., \& Barney, J. B. (2007). Corporate social responsibility and firm performance: Investor preferences and corporate strategies. Academy of management review, 32(3), 817-835.

[18] Malik, M. S., \& Nadeem, M. (2014). Impact of corporate social responsibility on the financial performance of banks in Pakistan. International Letters of Social and Humanistic Sciences, 10(1), 9-19.

[19] McGuire, J., Sundgren, A., \& Schneeweis, T. (1988, December). Corporate Social Responsibility and Firm Financial Performance. The Academy of Management Journal, 31(4), 854-872.

[20] Mehta, M., \& Chandani, A. (2015). Corporate Social Responsibility (CSR) Where Indian Pharma Corporates Stand-Study With Reference To Corporate Governance Practices and CSR Characteristics in a Lowpressure Turbine Engine. Indian Journal of Science and Technology, 8 , 76.

[21] Mishra, S., \& Suar, D. (2010). Does corporate social responsibility influence firm performance of Indian companies? Journal of Business Ethics, 95(4), 571-601

[22] Murtaza, I. A., Akhtar, N., Ijaz, A., \& Sadiqa, A. (2014). Impact of Corporate Social Responsibility on Firm Financial Performance: A Case Study of Pakistan. International Review of Management and Business Research, 3(4), 1914.

[23] Mustafa, S. A., Othman, A. R., \& Perumal, S. (2012). Corporate social responsibility and company performance in the Malaysian context. Procedia-Social and Behavioural Sciences, 65, 897-905

[24] Mwangi, C. I., \& Jerotich, O. J. (2013). The relationship between corporate social responsibility practices and financial performance of firm in the manufacturing, construction and allied sector of the Nairobi securities exchange. International Journal of Business, Humanities and Technology, 3(2).

[25] Pan, X., Sha, J., Zhang, H., \& Ke, W. (2014). Relationship between corporate social responsibility and financial performance in the mineral Industry: Evidence from Chinese mineral firms. Sustainability, 6(7), 40774101.

[26] Ramasamy, B., Ting, H. W., \& Yeung, M. C. (2007). Does it pay to be good in developing countries? The relationship between CSR and financial performance in Malaysia. Asian Academy of Management Journal of Accounting and Finance, 3(1), 21-36.

[27] Ramakrishnan, S., Hishan, S. S., Shahabuddin, A. S. M., \& Kanjanapathy, M. (2016). The Role of Corporate Social Responsibility in Flood Mitigation among the Listed Insurance Companies in Malaysia. International Review of Management and Marketing, 6(4S).

[28] Ramakrishnan, S., Hishan, S. S., \& Kanjanapathy, M. (2016). Corporate Social Responsibility in Malaysian Apparel Manufacturing Industry: A Study on Corporate Social Responsibility Website Reporting. International Review of Management and Marketing, 6(4S).

[29] Saleh, M., Zulkifli, N., \& Muhamad, R. (2011). Looking for evidence of the relationship between corporate social responsibility and corporate financial performance in an emerging market. Asia-Pacific Journal of Business Administration, 3(2), 165-190.

[30] Sapsford, R., \& Jupp, V. (Eds.). (2006). Data collection and analysis. Sage.

[31] Saremi, S. Y., Sarli, M., Botyari, E., \& Rad, F. H. (2012). Impact of Environment and Community on Performance of Malaysian Travel \& Leisure. International Conference on Economics, Business Innovation, 38(1), 69-72.

[32] Sharma, B. (2013). Contextualising CSR in Asia: Corporate social responsibility in Asian economies.

[33] Shirley, C., Suan, A. G., Leng, C. P., Okoth, M. O., Fei, N. B., \& PJU, K. D. (2009). Corporate social responsibility reporting in Malaysia: An analysis of Website reporting of Second Board companies listed in Bursa Malaysia. SEGI Review, 2(2), 85-110.

[34] Teoh, H. Y., \& Gregory Thong, T. S. (1981). An empirical research on corporate social responsibilities undertaken by Malaysian companies. Malaysian Management Review, August, 1-110.

[35] Wan Ahamed, W., Almsafir, M. K., \& Al-Smadi, A. W. (2014). Does Corporate Social Responsibility Lead to Improve in Firm Financial Performance? Evidence from Malaysia. International Journal of Economics and Finance, 6(3), 126-138.

[36] Yusoff, W. F. W., \& Adamu, M. S. (2016). The Relationship between Corporate Social Responsibility and Financial Performance: Evidence from Malaysia. International Business Management, 10(4), 345-351. 